\section{ekf}

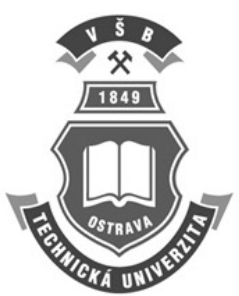

\title{
The 100 largest companies in the Czech Republic and Poland in the year 2010: a comparative study of economic performance
}

Mirosława SZEWCZYK, Opole University of Technology ${ }^{i}$

Krzysztof ŁOBOS, Opole School of Banking ${ }^{\text {ii }}$

\begin{abstract}
The main purpose of this paper is to compare the 100 largest Czech and Polish companies on the basis of selected measures of economic effectiveness and also with regard to other characteristics of their activities such as export activities and rationality of employment. A division of the examined group was introduced and included some companies which concentrate on production activity (Group P) and others whose activity focuses on trading and service (Group TS). A chi-square test of independence, a z-test and cluster analysis were used. The structure of the 100 largest companies, in regard to the application of the criterion of division into P and TS, was not significantly different. The Czech Group P enterprises seem to be, on average, slightly better managed than their Polish counterparts. The classification (cluster analysis) allowed the separation of six groups of companies into different characteristics.
\end{abstract}

\section{Keywords}

Economic effectiveness, export activities, productivity, top-100 enterprises.

JELClassification: L2, L6, L8, P52

\footnotetext{
${ }^{\mathrm{i}}$ Department of Economics and Regional Research, Faculty of Management, Opole University of Technology, Waryńskiego 4, 45-271 Opole, Poland.

ii Department of Management, Faculty of Economics, Opole School of Banking, Augustyna Kośnego 72, 45-372 Opole, Poland.

m.szewczyk@po.opole.pl (corresponding author)
}

\section{Introduction}

The largest enterprises are objects of interest not only because of the scale of their activity, but also because they create a peculiar visiting card of economies in states in which they function. They are a manifestation of the competitive advantages of their societies (Jarvinen et al., 2009). They are either managed in a modern and rational manner or require restructuring, which most often reflects the condition of the economy as a whole. In the process of attaining high levels of effectiveness in transforming and developing economies, an important role is played by foreign investments and privatization (Geršl, 2008; Szymanski et al., 2007; Ecevit et al., 2010; Kolasa et al., 2010).

The aim of this paper is to draw a comparison between the 100 largest Czech and Polish companies companies on the basis of selected measures of economic effectiveness and also such other characteristics of their activity as export activity and rationality of employment. The authors concentrated on grasping possible differences and similarities, as well as the causes behind them in the group of flagship companies of the economies of two countries which are neighbours in Central Europe. 
During the past decade, the Czech Republic and Poland have undergone significant political, economic and geopolitical changes (Klich and Poznańska, 2005; Kislingerová and Nový, 2005; Sedláček, 2007; Kołodko and Tomkiewicz, 2009; Kołodko, 2011; Kowalski 2009; Strouhal et al., 2009; Gočev, 2010; Klusáček et al., 2005; Brůha et al., 2010; Pazour et al., 2010). A comparative study of the economic performance between the Czech and the Polish largest companies would be interesting. The authors believe that there is a need for such comparative studies.

For the purposes of the analysis, our ranking includes companies in the Czech Republic and Poland. The Top 100 rankings are based on company revenues. Revenues and financial net result have been calculated in Euros at the relevant average exchange rates.

The structure of this paper is as follows: the first section presents the aims and a review of literature. In the second section, the data and methodology are identified for the empirical work. In Section Three, we discuss the structure of activity of the 100 largest companies in Poland and the Czech Republic. Section Four discusses the issue of economic effectiveness. Exports activity and management in the sphere of employment are examined in the fifth section. Section Six discusses the results and contains conclusions.

\section{Data and methods}

The sample includes 100 companies per country. On the basis of available data about the 100 largest enterprises ${ }^{1}$ in the Czech Republic and Poland (Lista 500, Największe firmy Rzeczpospolitej, 2011; Top100,2011 ), as regards the value of their sales in 2010, a comparative study was conducted, taking into account selected variables relating to economic effectiveness and other characteristics of business activity such as export activity and rationality of employment. A division of the group being examined was introduced into companies which concentrate on production activity (Group P) and those whose activity focuses on trading and service (Group TS). The data from all kinds of activity was presented in accordance with Classification of Economic Activities (CZNACE) for Czech entities, and the Polish Classification of Activity (PKD 2007) for Polish entities.

Descriptive statistics are used to describe the basic features of the data in the study. Together with simple graphics analysis, they provide simple summaries of the samples and the measures. The examination of the structure of business activity on the basis of the adopted divisive criterion concerning the top-100 in the Czech Republic and in Poland is carried out by means of a chi-square test of independence. The z-test is used to check the significance of mean differences for such variables as: sales revenues, financial net result, ROS (return on sales), share of export in sales and also employment and productivity of employment. In the paper, two of the most popular clustering techniques are presented in the framework of the data recovery approach (Ward method for hierarchical clustering and k-means for partitioning).

The examination of the structure of economic activity on the basis of the introduced criterion of division in the top-100 group in the Czech Republic and in Poland is conducted with the use of a chi-square test of independence (Mansfield, 1987; Ostasiewicz et al., 1997). There are two variables. One variable has $r$ levels, the other variable has $s$ levels. There are $r \cdot s$ observed frequencies (contingency table).

Null hypothesis

$\mathrm{H}_{0}$ : Variable A and variable B are independent.

An alternative hypothesis

$\mathrm{H}_{1}$ : Variable A and variable B are not independent.

The test statistic is

$$
\chi^{2}=\sum_{i=1}^{r} \sum_{j=1}^{s} \frac{\left(n_{i j}-\hat{n}_{i j}\right)^{2}}{\hat{n}_{i j}},
$$

where $\chi^{2}$ is the chi-square statistic, the $(i, j)$-th cell in the contingency table refers to the $i$-th row and $j$-th column in it, $n_{i j}$ is observed frequency in the $i$-th row and the $j$-th column, $\hat{n}_{i j}$ is expected (theoretical) frequency in the $i$-th row and the $j$-th column, $r$ is number of rows, and sis number of columns.

The z-test is used to test the significance of the difference between two sample means (Mansfield, 1987; Ostasiewicz et al., 1997). We recommend the use of ztest data analysis tool, because sample sizes are large. We recommend the use of z-test data analysis tool, because all sample sizes are large. The most basic theorem of the statistics, the Central Limit Theorem, requires large sample sizes in order to plot sample averages on a Normal curve, regardless of the underlying population distribution. Requirements: two independent populations, $\sigma_{1}$ and $\sigma_{2}$ are known, large samples.

Null hypothesis

$\mathrm{H}_{0}: \mu_{1}-\mu_{2}=0$.

An alternative hypothesis

$\mathrm{H}_{1}: \mu_{1}-\mu_{2}<0$.

The test statistic is

${ }^{1}$ Without financial and insurance activities. 


$$
z=\frac{\bar{x}_{1}-\bar{x}_{2}}{\sqrt{\frac{\sigma_{1}^{2}}{n_{1}}+\frac{\sigma_{2}^{2}}{n_{2}}}},
$$

where $\bar{x}_{1}$ and $\bar{x}_{2}$ are the means of the two samples, $\sigma_{1}$ and $\sigma_{2}$ are the standard deviations of the two populations $\left(\sigma_{1} \approx s_{1}\right.$ and $\sigma_{2} \approx S_{2}$ when $s_{1}$ and $s_{2}$ are the standard deviations of the two samples) and $n_{1}$ and $n_{2}$ are the sizes of the two samples.

If the significance level $\alpha$ (maximum probability of rejecting the null hypothesis when - in fact - it is true) were established as 0.05 , then definitely the $p$-value (probability of observing the observed test statistic value at least as unfavorable to the null hypothesis) being less than 0.05 would lead to the rejection of the null hypothesis.

The cluster analysis is an exploratory data analysis tool which aims at sorting different objects into groups so that that the degree of association between two objects is maximal if they belong to the same group and minimal otherwise. The term cluster analysis encompasses a number of different algorithms and methods for grouping objects of similar kind into respective categories. A general question facing researchers in many areas of inquiry is how to organize observed data into structures; that is, to develop taxonomies.

The Ward method is distinct from all other methods because it uses an analysis of variance approach to evaluate the distances between clusters. In short, this method attempts to minimize the Sum of Squares of any two (hypothetical) clusters that can be formed at each step. In general, this method is regarded as very efficient. However, it tends to create clusters of a small size. In $k$-means clustering, STATISTICA tries to move objects in and out of groups (clusters) to achieve the most significant results. The magnitude of the $F$ values from the analysis of variance performed on each dimension is another indication of how well the respective dimensions discriminate between clusters. It should be mentioned that the best number of $\mathrm{k}$ clusters leading to the greatest separation (distance) is not known apriori and must be computed from the data.

\section{The structure of activity of the 100 largest companies in the Czech Republic and Poland}

Based on juxtapositions of the top-100 largest Polish and Czech enterprises in terms of obtained revenues, a division was introduced into companies whose activity is of a typical production character and the ones that concentrate on trading activity (Tables 12-15). All of the analyzed companies belong to the group of large enterprises. Their activity is - as a consequence - varied both as regards the subjective side of the activity and the territorial one. Obviously, one should not expect the enterprises included in Group P (production companies) not to possess areas of activity of the typically trading nature and, on the other hand, those qualified as Group TS (trading and services) not to realize production activity at all. The concern here is rather with the proportions and accents of the activity. In the first case, the production activity is primary in some measure and is carried out to a broad extent. In the other case, the production activity is complementary in relation to trading. Apart from this, companies that provide services were also included in the other group, as introducing the third independent group of service-rendering firms would be impossible due to their poor representation. Consequently, it was decided to include them in that comprising trading enterprises in compliance with the tendency that in post-industrial economies firms of the typically production type are replaced by ones exploiting exchange of information, financial engineering, innovations, services (Tanabe and Watanabe, 2005).

In order to compare the structures of both economies seen through the prism of 100 of their largest enterprises, as well as relying on the above-introduced division, the hypothesis that, irrespective of the country (Poland or the Czech Republic), the structure of the activity of the 100 largest firms - from the point of view of the criterion $P$ or $T S$ - is alike, was examined with the use of a chi-square test of independence (Table 1).

Table 1 Contingency table for test of independence

\begin{tabular}{|l|c|c|}
\hline Group Country & Poland & Czech \\
\hline P & 38 & 49 \\
\hline TS & 62 & 51 \\
\hline
\end{tabular}

As regards the group of large enterprises, the Polish economy presents a more uneven structure in comparison with their Czech counterparts. This is expressed through the advantage of the share of trading and services-rendering firms in proportion to the production ones. As regards the Czech economy, on the other hand, we come to deal with a balance in this respect. In the authors' opinion, however, one should not suppose that this dominance of firms in Group P over those in Group TS in Poland finds its justification in a more post-industrial structure of the market. It should rather be expected that the much larger internal sales market in Poland creates chances for the appearance of large companies dealing in trading and services. The observed level of test significance amounted to $p=0.12$, that is greater than the assumed level of $\alpha=0.05$. Therefore, there is no reason to conclude that the structures of both econo- 
mies seen through the prism of their top-100 companies are different, having taken into account the division of the population into the groups of $\mathrm{P}$ and TS.

\section{The economic effectiveness of the 100 largest companies in the Czech Republic and in Poland}

The measures of effectiveness available for the examination included sales revenues, the net financial result (which comprises the result of operating activity, the result of financial operations, the result of extraordinary operations and obligatory encumbrances on financial result due to corporate income tax and equivalent payments, pursuant to separate provisions of law), the Return on Sales Ratio (ROS) and the Return on Assets Ratio (ROA). In order to obtain clarity of comparison, it was decided to render these values into Euros. In Tables 5-6 the basic descriptive statistics for sales revenues and net financial results are presented.

Within the scope of sales revenues in Group TS, on the basis of a z-test, it can be seen that the mean values of this measure are higher in the group of Polish companies than in the Czech ones ( $p=P(Z \leq z)=5.8 \cdot 10^{-8}$, at $\alpha=0.05$ ). It is then not only the numerousness of this group that is higher. It also generates higher revenues than the average. Therefore, it can be said that a factor exists which causes large enterprises of Group TS in Poland to function in a more favourable way due to the size of the realized sales. Perhaps this could be said to represent the above-mentioned size of the interior market. Table 5 also displays a greater range of changeability of sales revenues for the Polish top- 100 .

In the case of Group P, both for Poland and the Czech Republic, the value of statistic $\mathrm{z}$ for the variable of sales revenues amounted to $(-1.55)$, whereas probability $p=P(Z \leq z)=0.06$. It can thus be concluded that on the significance level of $\alpha=0.05$ there are no foundations to reject the hypothesis that mean sales revenues in the case of Group P in Poland and in the Czech Republic equal each other. Accepting the significance level of $\alpha=0.10$ results, it can be acknowledged that the mean sales revenues in the case of Group P in Poland and in the Czech Republic differ from each other in a significant way ${ }^{2}$. It can also be stated that in Group P, Polish companies realize, on

\footnotetext{
${ }^{2}$ Failure to reject the null hypothesis is not a proof of its validity but may rather be an indication that there is insufficient evidence to dispute it. The acceptance of the alternative hypothesis in contrast to failing to reject the null hypothesis is a positive result in that it supports the conjecture of interests.
}

average, greater revenues than the Czech ones. Irrespective of the interpretation, the difference is not, however, so distinctive as in Group TS.

Despite the differences observed in Table 6 containing the basic descriptive statistics related to the mean value of the net financial result in Group P, as well as TS in Poland and in the Czech Republic, they are not statistically significant.

As regards returns on sales (ROS) we do not observe any fundamental differences between the Polish and Czech Groups P or the Polish and Czech Groups TS (Table 7). The tests proved insignificant at the following results: for Group $\mathrm{P} \quad(z=(-0.20)$, $p=P(Z \leq z)=0.42), \quad$ and for Group TS ( $z=(-0.02), p=P(Z \leq z)=0.49)$. Thus, there is no basis to reject the null hypothesis on equality of ROS in Groups P and TS in Poland and in the Czech Republic. However, it is worth noticing that the values of ROS for Czech P companies are visibly higher.

In the research practice, during talks held with the management personnel of the enterprises, the thesis is often repeated that the nearer one approaches the end of the chain of value in a given branch, the higher the values of the realized margin. To simplify this a little, trade - according to this thesis - should be more effective by its nature than production. Tests of differences in mean return on sales (Groups $\mathrm{P}$ and TS from the Czech Republic and Poland were juxtaposed) turned out to be significant. But surprisingly, the mean value of ROS for Group P in both countries is higher than for Group TS. What is more, it seems to be a more understandable situation because higher profits from trade corporations can be gained through applying pressure only in the case of small and dependent manufacturing companies. In the case of large manufacturing companies, such pressure cannot be exerted. Higher profits are probably realized in Group P because their advantage is based on competencies (a more complicated mix of tough to imitate competencies - technical, logistic, service and so on). This seems to be a more natural situation - a more complicated mix of competencies means higher profits. The tests proved significant at the following results: for the Polish Group P and TS $p=P(Z \leq z)=0.009$, and for the Czech Group P and TS $p=P(Z \leq z)=0.0002$. Also the net financial result is higher for Group $\mathrm{P}$ in the Czech Republic, than for Group TS (but $p=P(Z \leq z)=0.08)$. It can be thus concluded that on the significance level of $\alpha=0.05$ there are no foundations to reject the hypothesis that the mean net financial result in the case of Group P and for Group TS in the Czech Republic equal each other. If one accepts the significance level of $\alpha=0.10$ this implies that one 
needs to acknowledge that the mean net financial result is significantly higher in the case of Group $\mathrm{P}$ in the Czech Republic than for Group TS.

As regards the Return on Assets Ratio (ROA, Table 8$)$ tests proved significant only for Polish and Czech Groups $\mathrm{P}$ with $p=P(Z \leq z)=0.01$. The ROA reflects in general the rationality of investing in assets needed to act in a given domain (Sierpińska and Jachna, 1994; Tyran, 2005). Thus, we can presume that the assets of the Czech enterprises which compose group $\mathrm{P}$ are more productive, maybe also more modern and are adjusted to the current competition. This situation may also be connected with the greater openness of Czech manufacturing companies in view of foreign sales, as we describe in next paragraph.

\section{Selected characteristics of the $\mathbf{1 0 0}$ largest companies in the Czech Republic and in Poland}

The available data allowed for analyzing such characteristics of the examined companies as exports activity and management in the sphere of employment. Tables 9-10present descriptive statistics of the share of exports in sales revenues and employment.

An important and interesting characteristic of the enterprises being examined is their activity in the scope of exports. The share of foreign sales is significantly higher for Czech manufacturing companies $(p=P(Z \leq z)=0.08)$ (by a significance level of $\alpha=0.1$ ). This seems to be related to the fact that Czech manufacturing companies are, slightly more often than in Poland, subsidiaries of large international companies (Skoda, Siemens, Bosch, Toyota, Peugeot, Citroen), which forces management to introduce upto-date management systems and improved technology and stimulates cost control. This may be the main reason for the observed difference in ROA and even the ROS mean level between the Polish and Czech Group P (see previous paragraph). The Czech Group P seems to be more modern than Group P in Poland. For Groups TS from Poland and the Czech Republic z-test did not prove to be significant $(z=(-0.23)$, $p=P(Z \leq z)=0.41)$. It is simply less possible to export services to a greater extent. Therefore, trade and sales companies mainly try to be present in the internal market.

As far as the question of employment is concerned, the Polish companies both included in Group P and Group TS are generally larger. The changeability in their employment is also greater. This observation can also be confirmed by $z$-test, both for Group P and Group TS. In the case of the former, the value of statistic $\mathrm{z}$ for the employment variable for Group P amounted to $(-2.59)$, whereas the probability was
$p=P(Z \leq z)=0.005$. With reference to Group TS, analogous results amounted to the following: $z=(-1.57)$, while $p=P(Z \leq z)=0.06$.

The level of employment itself does not, however, carry information about the effectiveness of its usage; nor does it provide information about the effectiveness of management. Therefore, it was decided that the productivity of employment should be approximated by referring it to the value of the realized sales given in the Euro. The medial values of productivity were calculated on the basis of cases provided by the enterprises for which both data were supplied. The obtained information should be treated with caution, since part of the companies did not make the data on employment available. Generally, the Czech enterprises display a higher mean value of employment productivity than the Polish ones for Group P. One worker employed in a Czech company of the top-100 generates about Euro 1,070 thousand revenue annually, while the value generated by one person employed in a Polish enterprise in Group P amounts to Euro 325 thousand. In Group TS, higher employment productivity can be observed in the case of the Polish companies. Answering the question about whether the other companies are managed in a similar manner, as in the Czech Republic, would require conducting further research. The mean values of productivity in division into companies from both countries and the distinguished groups (P and TS) are presented in Table 11. It needs to be added that employment productivity did not prove significantly different while comparing the Polish and Czech Groups P or TS. For Group P $p=P(Z \leq z)=0.22$, and for Group TS $p=P(Z \leq z)=0.49$.

\section{Cluster analysis}

One of the biggest problems with cluster analysis is identifying the optimum number of clusters. Because we usually do not know the number of groups or clusters that will emerge in our sample and because we want an optimum solution, a two-stage sequence of analysis will occur as follows:

- We will carry out a hierarchical cluster analysis using the Ward method. This helps to determine the optimum number of clusters we should work with.

- The next stage will be to rerun the hierarchical cluster analysis with our selected number of clusters, which enables us to allocate every case in our sample to a particular cluster.

This sequence and methodology using STATISTICA is used in analyzing the following variables: ROS, ROA and productivity. The research will be carried out into 
133 entities: 78 entities in Czech and 55 entities in Poland.

Deciding upon the optimum number of clusters is largely subjective, although looking at a dendrogram (see Figure 1) may help. An analysis is run and five major clusters stand out on the dendrogram. This is then quantified using a k-means cluster analysis with six clusters, which reveals that the means of different measures do indeed produce the six clusters.

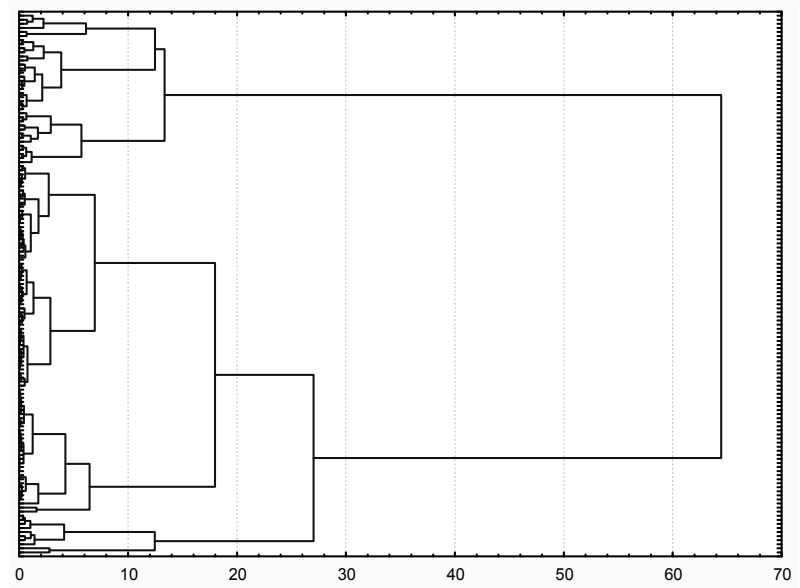

Figure1Dendrogram using Ward method (distances)

Table 2 outlines the $F$-statistics for each variable. Results indicate that all variables in the procedure were statistically significant at $p<0.05$.

Table 2 F-statistics for three variables

\begin{tabular}{|l|c|c|}
\hline Specification & $F$ & $p$-value \\
\hline ROS & 56.4 & $0.000^{*}$ \\
\hline ROA & 118.9 & $0.000^{*}$ \\
\hline Productivity & 71.6 & $0.000^{*}$ \\
\hline
\end{tabular}

* significant at the $5 \%$ level

Table 3 outlines cluster membership based on the $k$-means clustering solution. Clusters II and VI include enterprises of the best economic standing of all those being analyzed. Ratios ROA, ROS, as well as the productivity of employment are at a high level. Also, good economic standing characterizes companies of Cluster III. The companies of Clusters I, IV and V are the weakest as they operate on very low, close to zero, values of ROS, and low values of ROA.

Cluster I seems to be relatively weak in terms of economic effectiveness. It is composed of 3 Czech and 3 Polish enterprises. Sales revenue and employment figures indicate the extent of activities, allowing for classifying this cluster as being composed of comparatively smaller enterprises. Cluster I is strange, among the others, because the low values of ROA and ROS correspond here to very low employment and - in effect - very high productivity of employment. This is not typically representative of the top-100 companies.
We need to deal here either with companies that are very conveniently located within the value chain, are small in terms of employment, or intermediary companies from Group TS that are weak in view of economic effectiveness compared to manufacturing companies like RWE Transgas, a.s. and ALPIQ $E N E R G Y S E$. Due to slightly unclear characteristics, it is difficult to recommend restructuring actions for this group of companies.

Table 3 Statistics (mean values) for free variables for clusters I-VI

\begin{tabular}{|l|c|c|c|c|}
\hline Specification & $\begin{array}{c}\text { ROS } \\
(\%)\end{array}$ & $\begin{array}{c}\text { ROA } \\
(\%)\end{array}$ & $\begin{array}{c}\text { Productivity } \\
\text { (thousands of } \\
\text { Euro) }\end{array}$ & $\begin{array}{c}\text { Number of } \\
\text { companies }\end{array}$ \\
\hline Cluster I & -0.6 & 0.5 & 25,412 & 6 \\
\hline Cluster II & 10.3 & 19.6 & 1,018 & 20 \\
\hline Cluster III & 6.1 & 6.7 & 921 & 45 \\
\hline Cluster IV & 0.9 & 1.3 & 760 & 50 \\
\hline Cluster V & -2.0 & -2.1 & 26 & 2 \\
\hline Cluster VI & 29.1 & 16.8 & 228 & 10 \\
\hline
\end{tabular}

The second cluster is composed of 8 Polish and 12 Czech enterprises. It includes enterprises of the best economic standing (a high level of ROA, ROS, as well as the productivity of employment). It is impossible to find the common denominator in view of the branches represented here. Among enterprises we name: Makro Cash \& Carry $\check{C} R$, Siemens Group $\check{C} R$, Philips Lighting Poland, Totalizator Sportowy, Weglokoks, Polkomtel. As regards this group, one can mainly recommend monitoring the competitive situation in order to grasp early signals of changes of business models and configurations of their own strategic groups (direct competitors), which could undermine the strong position of the companies.

The third cluster is composed of 23 Polish and 22 Czech enterprises. These are rather large enterprises which are well-known on the international market. They include: Skoda, Bosch, Iveco, Saint-Gobain, Strabag, Skanska, Fiat, Michelin and others. As in almost every other cluster, it is impossible to find the common denominator as regards the branches represented here. Management-related actions in this group will depend to a great extent on the policies of central headquarters localized abroad. It is hard then to suggest actions other than traditional concern for operating activity and the most significant measures of effectiveness.

Cluster IV seems to be relatively weak in terms of economic effectiveness. Only a few of them are internationally well-known (Samsung, Electrolux, Fiat, LG, Arcellor Mittal). Many of the companies in Cluster IV are known for their need for vital restructuring processes (České dráhy, ČD Cargo, Polskie 
Linie Lotnicze LOT SA, Katowicki Holding Weglowy $S A G K$ and others). With respect to low values of profitability, the boards of these companies need to pay particular attention to the management of operating costs and fixed assets as well as working capital, inventories and receivables. The low values of profitability may give rise to problems as regards a rise in the value of equity. Stronger interest should be recommended in optimizing free cash flows, which result in higher values of residual profit and EVA (Economic Value Added).

Cluster V is composed of two enterprises. They are known for a vital need for restructuring processes (Správa železnični dopravni cesty, státni organizace, PKP, Polskie Linie Kolejowe SA). Their management system leaves a lot to be desired. As a result of traditional focus on problems of the inside of the organization and closing to relations with its market environment, PKP (Polish State Railways) has recently lost the opportunity for making use of the EU-granted means for restructuring the quota Euro 1.8 billion. There is an urgent need for restructuring the management systems of companies within this group with respect to clients' requirements, as well as modern conditions of competition. Strategic management in such large enterprises should find its due place in the end.

The relatively small Cluster VI (10 companies) displays high values of ROS, ROA, but a low value of productivity of employment. It is composed of enterprises which in many cases represent traditional, material and industrial branches (KGHM Polska Miedź SA, Severočeské doly a.s., Sokolovská uhelná, Lesy České republiky). Their economic condition seems to be stable, but high employment indicates low productiveness. Cluster VI is composed of 9 Czech and 1 Polish enterprises. It displays prevalence of manufacturing companies. Three companies in Cluster
IV belong to the mining and quarrying sector. Regarding the traditional character of enterprises included in this group, attention should be paid in them in terms of human resources management, and - especially - to the fixed, traditional nature of work positions and specialization (work distribution). It is necessary to analyze the procedures of carrying out jobs with respect to optimization (e.g., taking into account possibilities that offer as a result of IT technologies), as well as those work positions which depend on specific tasks being performed.

Table 4 presents the characteristics and recommended actions for clusters I-VI. The authors are planning to conduct further research into the largest companies in both countries in the following years. This should cover the present and prospective group of the 100 largest enterprises, along with an explanation of why the places in the ranking are changing. It is intended to cover stronger liaisons between observed economic effectiveness and the most crucial decisions within companies and changes in their business situations. It is also important to grasp certain typical developmental trajectories that may lead to weakening the economic results of large companies.

\section{Conclusions}

The aim of this paper was to make a comparison between the Czech and the Polish 100 largest companies on the basis of selected measures of economic effectiveness and also such other characteristics of their activity. On the basis of available data on 100 largest enterprises in the Czech Republic and in Poland, as regards the value of their sales in 2010, and a comparative study was conducted.

In order to grasp eventual similarities and differences within the 100 largest companies in the Czech Republic and in Poland, a criterion was selected

Table 4 The characteristics and recommended actions for clusters I-VI

\begin{tabular}{|l|c|c|}
\hline Specification & Brief characteristics & Recommended actions \\
\hline Cluster I & $\begin{array}{c}\text { Mainly companies in the sector of electric power } \\
\text { generation, transmission and distribution, the } \\
\text { weakest in view of economic effectiveness }\end{array}$ & - \\
\hline Cluster II & Good economic effectiveness & $\begin{array}{c}\text { Constant monitoring of the competitive situation and } \\
\text { business models }\end{array}$ \\
\hline Cluster III & $\begin{array}{c}\text { Many companies well-known on international } \\
\text { markets, mainly traditional branches represented, } \\
\text { high economic effectiveness }\end{array}$ & $\begin{array}{c}\text { Constant care of operating activity and the most } \\
\text { significant measures of effectiveness }\end{array}$ \\
\hline Cluster IV & $\begin{array}{c}\text { High employment, the weakest as regards } \\
\text { economic effectiveness }\end{array}$ & $\begin{array}{c}\text { Optimizing management of operating costs, fixed assets } \\
\text { and working capital. Paying attention to cash flows }\end{array}$ \\
\hline Cluster V & $\begin{array}{c}\text { The weakest cluster in terms of economic effec- } \\
\text { tiveness, companies demanding restructuring }\end{array}$ & $\begin{array}{c}\text { Restructuring management systems as regards clients' } \\
\text { needs and new conditions of competition. Opening to } \\
\text { relations with environment, strategic management }\end{array}$ \\
\hline Cluster VI & $\begin{array}{c}\text { Mainly traditional branches represented, very good } \\
\text { economic effectiveness }\end{array}$ & $\begin{array}{c}\text { Optimizing employment and paying attention to HR } \\
\text { function }\end{array}$ \\
\hline
\end{tabular}


requiring a division of the research sample into companies that are concentrated to a greater extent on trading and rendering services (Group TS) or production activity (Group P). It proved possible to effectively differentiate between the enterprises being examined. This could not be carried out on the basis of the criteria of product or territorial diversification (essentially all firms are to some degree diversified). On the basis of this division, analyses were carried out which showed certain similarities and differences, and their probable causes were indicated.

With regard to rough data on sales revenues, the net financial results show that their values are higher in the case of the Polish Group P enterprises than those of the Czech Group P, but ratios like ROS, ROA and also share of foreign sales, which indicate rationality of management are higher (significantly or not) for the Czech enterprises. The main reason seems to be related to the fact that Czech manufacturing companies are more often than in Poland subsidiaries of large international companies (Skoda, Siemens, Bosch, Toyota, Peugeot Citroen), which forces the managements to introduce up-to-date management systems, reliable technology and stimulates cost control. In turn, in Poland, there are also many enterprises which are based on foreign investments, but also many enterprises like Lasy Państwowe, Katowicki Holding Węglowy, Kompania Węglowa or Tauron, in which problems with management still occur.

Trade and service companies (Group TS) are in similar in many ways. To be sure, sales revenues and the net financial result are higher for Polish Group TS companies, but there are no clear differences as regards ROA, ROE and the share of exports of sales revenues. The reason for higher values of sales revenue and the net financial result for Polish TS is related, in the authors' opinion, to the bigger internal market.

As an effect of cluster analysis we isolated six clusters with the following generalized descriptions: (1) mainly companies in the sector of electric power generation, transmission and distribution, weak in view of economic effectiveness, (2) enterprises of the best economic standing (a high level of ROA, ROS, as well as the productivity of employment). For this group of companies, monitoring the competitive situation and competitive models of business in order to defend their own market position is recommended, (3) a cluster of many companies which are wellknown on international markets, with high employment and good economic effectiveness and strategic actions depend here mainly on decisions in central headquarters, while there are constant concerns about the operating rationality and monitoring measures of effectiveness, (4) relatively weak in view of economic effectiveness, but also highly differentiated, including many companies that require restructuring. In this group there is a need for optimization of management of operating costs, fixed assets and working capital, and attention needs to be paid to cash flows that generate the value of their own capital, (5) the weakest cluster in view of economic effectiveness, comprising two companies that require restructuring, wherein a strong need for re-configuration of management systems regarding clients' needs and opening of management to relations with the surrounding environment occurs, (6) a cluster of companies with very good economic effectiveness, operating in mainly traditional branches, an analysis of HR policy to date, as well as optimization within rationality of employment are suggested. There are no clear relations between the composition of a cluster in view of the location of an enterprise in Poland or the Czech Republic, or belonging to Group P or TS and their economic effectiveness. We observe evident prevalence of companies with a stable economic condition over weak companies which are in need of restructuring processes in both Polish and Czech groups.

The structure of both economies can be seen through the prism of the 100 largest companies, due to the application of the criterion of division into $\mathrm{P}$ and TS not being significantly different. Trade and service companies (Group TS) exist in many different dimensions (ROA, ROE and the share of exports in sales revenues) is similar. The Czech Group $\mathrm{P}$ enterprises seem to be, on average, slightly better managed than Polish Group P enterprises.

\section{References}

BRŮHA, J., PODPIERA, J., POLÁK, S. (2010). The convergence dynamics of a transition economy: the case of the Czech Republic. Economic Modelling 27(1): 116-124.

http://dx.doi.org/10.1016/j.econmod.2009.07.026

ECEVIT, E., DUZGUN, R., TURKER, O. (2010). Reflections on privatisation and international direct investment into the Turkish economy: the case of Turkey's first and next top 500 industrial enterprises. The Journal of Faculty of Economics and Administrative Science, Suleyman Dermirel University 15(1): 175-192.

GABRUSEWICZ, W. (2005). Podstawy analizy finansowej.Warszawa: PWE.

GERŠL, A. (2008). Productivity, export performance, and financing of the Czech corporate sector: the effects of foreign direct investment. Czech Journal of Economics and Finance (Finance a úvěr) 58(5-6): 232-247. 
GOČEV, P. (2010). Může přerozdělování posílit konkurenceschopnost ekonomiky? Politická ekonomie 58(6): 805-813.

JARVINEN, J., LAMBERG, J-A., MURMANN, J-P., OJALA, J. (2009). Alternative paths to competitive advantage: a fuzzy-set analysis of the origins of the large firms. Industry and Innovation 16(6): 545-574. http://dx.doi.org/10.1080/13662710903371066

KLICH, K., POZNAŃSKA, K. (2005). The Political Economy of Poland's Transition. New Firms and Reform Governments. New York: Cambridge University Press.

KISLINGEROVÁ E., NOVÝ I. (2005). Chování podniku v globalizujicím se prostředí. Prague: C.H. Beck.

KLUSÁČEK, K., et al. (2005). Final Report of the Project on CSF Evaluation 4/04 Barriers to the Growth of Competitiveness of the Czech Republic. Prague: Ministry for Regional Development of the Czech Republic.

KOLASA, M., RUBASZEK, M., TAGLIONI, D. (2010). Firms in the great global recession: the role of foreign ownership and financial dependence. National Bank of Poland Working Paper, No. 77. Warsaw: National Bank of Poland.

KOŁODKO G. (2011). Truth, Errors and Lies. Politics and Economics in a Volatile World. New York: Columbia University Press.

KOŁODKO, G., TOMKIEWICZ, J., (2009). 20 lattransformacji.Osiagnięcia, problemy, perspektywy. Warszawa: Wydawnictwa Akademickie i Profesjonalne.

KOWALSKI, T. (2009). Comparative analysis of economic transformation in Poland and selected central European countries. Working Papers in Management, Finance and Economics, No. 1(8). Poznań: Poznan University of Economics.

MANSFIELD, E. (1987). Statistics for Business and Economics. Methods and Applications. New York, London: Norton and Company.
OSTASIEWICZ, S., RUSNAK, Z., SIEDLECKA, U. (1997). Statystyka. Elementy teorii izadania. Wrocław: Wydawnictwo Akademii Ekonomicznej im. Oskara Langego.

NISBET, R., ELDER, J., MINER, G. (2009). Handbook of Statistical Analysis and Data Mining Applications. Burlington, MA: Academic Press (Elsevier).

PAZOUR, M., MRÁČEK, K., KUČERA, Z. (2010). Podnikový výzkum a vývoj $\mathrm{v}$ období hospodářské recese - trendy a očekávání. Ergo - Analýzy a trendy výzkumu, technologií a inovací 4(4): 9-13.

SEDLÁČEK, J. (2007). Analysis of the financial burden of the Czech enterprises in the period 19962005. Journal of Economics 55(6): 582-593.

SIERPIŃSKA, M., JACHNA, T. (1994). Ocena przedsiębiorstwa wedlug standardów światowych. Warszawa: PWN.

STROUHAL J., MÜLLEROVÁ L., CARDOVÁ Z., PASEKOVÁ M. (2009). National and international financial reporting rules: testing the compatibility of Czech reporting from SMEs perspective. WSEAS Transactions on Business and Economics 6(12): 620629.

SZYMANSKI, A., GORTON, M., HUBBARD, L. (2007). A comparative analysis of firm performance in post-socialists economies: evidence from the Polish food processing industry. Post-communist Economies 19(4): 433-448.

http://dx.doi.org/10.1080/14631370701680113

TANABE, K., WATANABE, C. (2005). Sources of small and medium enterprises excellent business performance in a service oriented economy. Journal of Service Research 5(1): 5-20.

TYRAN, M.R. (2005). Wskaźniki finansowe. Kraków: Oficyna Ekonomiczna.

\section{Additional sources}

Rzeczpospolita (2011). Lista 500. Największe firmy Rzeczpospolitej. [Online], accessed at 08. 10. 2011. Available at: <http://www.rp.pl>.

Top-100 (2011). [Online], accessed at 18. 09. 2011. Available at: $<$ http://www.czechtop100.cz/>. 


\section{Appendix}

Table 5 Sales revenues (thousands of Euro)

\begin{tabular}{|l|c|c|c|c|c|c|c|}
\hline Specification & Min & Max & Mean & $\begin{array}{c}\text { Standard } \\
\text { deviation }\end{array}$ & First quartile & Median & Third quartile \\
\hline TS - Czech & 190,816 & $2,292,654$ & 651,183 & 534,091 & 261,007 & 459,793 & 832,684 \\
\hline TS - Poland & 633,532 & $5,059,439$ & $1,315,660$ & 792,441 & 832,776 & $1,019,251$ & $1,611,026$ \\
\hline P - Czech & 186,071 & $8,748,666$ & $1,220,443$ & $1,826,869$ & 330,793 & 439,421 & $1,195,836$ \\
\hline P - Poland & 662,978 & $20,908,289$ & $2,170,419$ & $3,414,230$ & 858,152 & 952,858 & $2,008,730$ \\
\hline
\end{tabular}

Table 6 Net financial result (thousands of Euro)

\begin{tabular}{|l|c|c|c|c|c|c|c|}
\hline Specification & Min & Max & Mean & $\begin{array}{c}\text { Standard } \\
\text { deviation }\end{array}$ & First quartile & Median & Third quartile \\
\hline TS - Czech & $-72,954$ & 609,132 & 34,633 & 111,646 & 734 & 7,828 & 18,522 \\
\hline TS - Poland & $-123,284$ & $20,217,012$ & 571,210 & $3,273,692$ & 9,413 & 29,730 & 53,669 \\
\hline P - Czech & $-302,625$ & $2,344,152$ & 114,755 & 363,478 & 12,780 & 38,270 & 97,537 \\
\hline P - Poland & $-20,434$ & $1,179,925$ & 169,262 & 277,805 & 26,849 & 72,023 & 144,097 \\
\hline
\end{tabular}

Table 7 Return on sales ratio (\%)

\begin{tabular}{|l|c|c|c|c|c|c|c|}
\hline Specification & Min & Max & Mean & $\begin{array}{c}\text { Standard } \\
\text { deviation }\end{array}$ & First quartile & Median & Third quartile \\
\hline TS - Czech & -27.3 & 5.6 & 3.2 & 9.0 & 0.2 & 1.6 & 3.3 \\
\hline TS - Poland & -13.1 & 15.4 & 3.5 & 5.2 & 1.1 & 1.6 & 6.1 \\
\hline P - Czech & -6.4 & 41.2 & 10.9 & 11.4 & 3.0 & 6.1 & 16.6 \\
\hline P - Poland & -0.5 & 27.3 & 6.8 & 6.2 & 2.4 & 5.7 & 9.4 \\
\hline
\end{tabular}

Table 8 Return on assets ratio (\%)

\begin{tabular}{|l|c|c|c|c|c|c|c|}
\hline Specification & Min & Max & Mean & $\begin{array}{c}\text { Standard } \\
\text { deviation }\end{array}$ & First quartile & Median & Third quartile \\
\hline TS - Czech & -2.7 & 32.2 & 5.9 & 8.1 & 0.7 & 3.3 & 6.9 \\
\hline TS - Poland & -10.8 & 21.7 & 4.9 & 5.8 & 2.0 & 4.2 & 6.3 \\
\hline P - Czech & -5.6 & 36.1 & 9.1 & 9.4 & 2.5 & 6.8 & 13.9 \\
\hline P - Poland & -1.2 & 30.3 & 8.4 & 7.5 & 3.4 & 7.0 & 11.8 \\
\hline
\end{tabular}

Table 9 Share of exports in sales revenues (\%)

\begin{tabular}{|l|c|c|c|c|c|c|c|}
\hline Specification & Min & Max & Mean & $\begin{array}{c}\text { Standard } \\
\text { deviation }\end{array}$ & First quartile & Median & Third quartile \\
\hline TS - Czech & 0 & 78 & 13 & 18 & 2 & 7 & 19 \\
\hline TS - Poland & 0 & 92 & 12 & 26 & 0 & 0 & 8 \\
\hline P - Czech & 0 & 100 & 62 & 35 & 35 & 73 & 94 \\
\hline P - Poland & 0 & 98 & 48 & 41 & 2 & 70 & 81 \\
\hline
\end{tabular}

Table 10 Employment

\begin{tabular}{|l|c|c|c|c|c|c|c|}
\hline Specification & Min & Max & Mean & $\begin{array}{c}\text { Standard } \\
\text { deviation }\end{array}$ & First quartile & Median & Third quartile \\
\hline TS - Czech & 37 & 38,046 & 4,280 & 7,703 & 400 & 1,880 & 4,454 \\
\hline TS - Poland & 18 & 39,846 & 6,967 & 8,571 & 1,046 & 3,863 & 9,055 \\
\hline P - Czech & 115 & 33,126 & 4,113 & 6,450 & 1,085 & 2,067 & 3,981 \\
\hline P - Poland & 890 & 62,103 & 11,039 & 14,243 & 2,907 & 4,606 & 12,350 \\
\hline
\end{tabular}


Table 11 Productivity (thousands of Euro)

\begin{tabular}{|l|c|c|c|c|c|c|c|}
\hline Specification & Min & Max & Mean & $\begin{array}{c}\text { Standard } \\
\text { deviation }\end{array}$ & First quartile & Median & Third quartile \\
\hline TS - Czech & 23 & 20,311 & 2,165 & 4,698 & 96 & 272 & 914 \\
\hline TS - Poland & 24 & 52,308 & 3,348 & 9,562 & 133 & 251 & 1,000 \\
\hline P - Czech & 76 & 15,275 & 1,070 & 3,179 & 137 & 209 & 573 \\
\hline P - Poland & 42 & 1,049 & 325 & 292 & 139 & 194 & 437 \\
\hline
\end{tabular}

Table 12 Profiles of the examined subjects (Group P - Czech Republic)

\begin{tabular}{|c|c|}
\hline Name & Profile \\
\hline AGROFERT HOLDING, a.s.; LESS a.s.; Lesy České republiky, s.p. & Agriculture, hunting and forestry \\
\hline OKD, a.s.; Severočeské doly a.s.; Sokolovská uhelná, právní nástupce, a.s. & Mining and quarrying \\
\hline $\begin{array}{l}\text { ArcelorMittal Ostrava a.s.; TŘINECKÉ ŽELEZÁRNY, a.s.; Vítkovice Holding } \\
\text { a.s. }\end{array}$ & $\begin{array}{l}\text { Manufacture of basic metals and fabricated } \\
\text { metal products }\end{array}$ \\
\hline $\begin{array}{l}\text { ČEPRO, a.s.; ČESKÁ RAFINÉRSKÁ, a.s.; DEZA, a.s.; Linde Gas a.s.; } \\
\text { MITAS a.s.; UNIPETROL, a.s. }\end{array}$ & $\begin{array}{l}\text { Manufacture of chemicals and chemical } \\
\text { products; manufacture of rubber and plastic } \\
\text { products }\end{array}$ \\
\hline $\begin{array}{l}\text { ABB s.r.o.; Eaton Elektrotechnika s.r.o.; FOXCONN CZ s.r.o.; Panasonic } \\
\text { AVC Networks Czech, s.r.o.; WITTE Nejdek, s.r.o.; Daikin Industries Czech } \\
\text { Republic s.r.o. }\end{array}$ & $\begin{array}{l}\text { Manufacture of electrical and optical equip- } \\
\text { ment }\end{array}$ \\
\hline NOWACO Czech Republic s.r.o.; Philip Morris ČR a.s.; Plzeňský Prazdroj, a.s. & $\begin{array}{l}\text { Manufacture of food products and beverages; } \\
\text { manufacture of tobacco products }\end{array}$ \\
\hline $\begin{array}{l}\text { DENSO MANUFACTURING CZECH s.r.o.; Siemens Industrial Turbomachin- } \\
\text { ery s.r.o.; BOSCH Group ČR; SIEMENS Group ČR }\end{array}$ & $\begin{array}{l}\text { Manufacture of machinery and equipment } \\
\text { n.e.c. }\end{array}$ \\
\hline $\begin{array}{l}\text { Automotive Lighting s.r.o.; BOSCH DIESEL s.r.o.; Continental Automotive } \\
\text { Systems Czech Republic s.r.o.; Iveco Czech Republic, a.s.; Magna Exteriors \& } \\
\text { Interiors (Bohemia) s.r.o.; Robert Bosch, s.r.o.; ŠKODA AUTO a.s.; Toyota } \\
\text { Peugeot Citroën Automobile Czech, s.r.o.; TRW Automotive Czech s.r.o; } \\
\text { Visteon - Autopal, s.r.o. }\end{array}$ & $\begin{array}{l}\text { Manufacture of motor vehicles, trailers and } \\
\text { semi-trailers; Manufacture of other transport } \\
\text { equipment }\end{array}$ \\
\hline AGC Flat Glass Czech a.s., člen AGC Group; Saint-Gobain Vertex, a.s. & $\begin{array}{l}\text { Manufacture of other non-metallic mineral } \\
\text { products }\end{array}$ \\
\hline Mondi Štětí a.s. & $\begin{array}{l}\text { Manufacture of wood and wood products; } \\
\text { manufacture of pulp, paper and paper } \\
\text { products; publishing and printing }\end{array}$ \\
\hline $\begin{array}{l}\text { ALPIQ ENERGY SE; ČEPS, a.s.; ČEZ, a.s.; Dalkia Česká republika, a.s.; } \\
\text { Pražská energetika, a.s.; Pražská plynárenská, a.s.; RWE Transgas, a.s.; Veolia } \\
\text { Voda Česká republika, a.s. }\end{array}$ & Electricity \\
\hline
\end{tabular}


Table 13 Profiles of the examined subjects (TS - Czech Republic)

\begin{tabular}{|c|c|}
\hline Name & Profile \\
\hline eD' system Czech, a.s.; HEWLETT-PACKARD s.r.o.; SWS a.s. & Computer and related activities \\
\hline $\begin{array}{l}\text { EUROVIA CS, a.s.; Metrostav a.s.; OHL ŽS, a.s.; PSG-International a.s.; PSJ, } \\
\text { a.s.; Skanska a.s.; SKKODA PRAHA Invest s.r.o.; STRABAG a.s. }\end{array}$ & Construction \\
\hline $\begin{array}{l}\text { ČESKÁ TELEVIZE; Fakultní nemocnice Brno; Fakultní nemocnice Hradec } \\
\text { Králové; Fakultní nemocnice Plzeň; Všeobecná fakultní nemocnice v Praze }\end{array}$ & $\begin{array}{l}\text { Other community, social and personal service } \\
\text { activities }\end{array}$ \\
\hline $\begin{array}{l}\text { Česká pošta, s.p.; GTS Czech s.r.o.; Telefónica O2 Czech Republic, a.s.; } \\
\text { T-Mobile Czech Republic a.s.; Vodafone Czech Republic a.s. }\end{array}$ & Post and telecommunications \\
\hline AGEL a.s. & Real estate, renting and business activities \\
\hline $\begin{array}{l}\text { ENI Česká republika, s.r.o.; FORD MOTOR COMPANY, s.r.o.; Import } \\
\text { Volkswagen Group s.r.o.; LUKOIL Czech Republic s.r.o.; OMV Česká } \\
\text { republika, s.r.o.; Shell Czech Republic a.s.; Slovnaft Česká republika, s.r.o. }\end{array}$ & $\begin{array}{l}\text { Sale, maintenance and repair of motor } \\
\text { vehicles and motorcycles; retail sale of } \\
\text { automotive fuel }\end{array}$ \\
\hline $\begin{array}{l}\text { Advanced World Transport B.V.; ČD Cargo, a.s.; České dráhy, a.s.; Letiště } \\
\text { Praha, a.s.; Správa železniční dopravní cesty, státní organizace }\end{array}$ & Transport, storage and communication \\
\hline $\begin{array}{l}\text { AHOLD Czech Republic, a.s.; ALTA, akciová společnost; AT Computers, a.s.; } \\
\text { CARBOUNION BOHEMIA, s.r.o.; COOP Centrum družstvo; DEK a.s.; } \\
\text { Ferona, a.s.; GECO TABAK, a.s.; Globus ČR, k.s.; HRUŠKA, s.r.o.; HP } \\
\text { TRONIC Zlín, s.r.o.; Lumius, s.r.o.; MAKRO Cash \& Carry ČR s.r.o.; } \\
\text { METALIMEX a.s.; MORAVIA STEEL a.s.; PHARMOS, a.s.; První novinová } \\
\text { společnost a.s. }\end{array}$ & $\begin{array}{l}\text { Wholesale trade and commission trade, } \\
\text { except of motor vehicles and motorcycles; } \\
\text { Retail trade, except of motor vehicles and } \\
\text { motorcycles; repair of personal and house- } \\
\text { hold goods }\end{array}$ \\
\hline
\end{tabular}

Table 14 Profiles of the examined subjects (Group P-Poland)

\begin{tabular}{|c|c|}
\hline Name & Profile \\
\hline Lasy Państwowe PGL & Agriculture, forestry and fishing \\
\hline $\begin{array}{l}\text { Jastrzębska Spółka Węglowa SA; Katowicki Holding Węglowy SA GK; } \\
\text { KGHM Polska Miedź SA GK; Kompania Węglowa SA; PGNiG SA GK }\end{array}$ & Mining and quarrying \\
\hline Nestle SA & Manufacture of food products \\
\hline Grupa Żywiec SA GK; Kompania Piwowarska SA GK & Manufacture of beverages \\
\hline Grupa Lotos SA GK; Koksownia Przyjaźń Sp. z o.o.; PKN Orlen SA GK & $\begin{array}{l}\text { Manufacture of coke and refined petroleum } \\
\text { products }\end{array}$ \\
\hline Boryszew SA GK; Ciech SA GK & $\begin{array}{l}\text { Manufacture of chemicals and chemical } \\
\text { products }\end{array}$ \\
\hline SHARP Manufacturing Poland; Tele-Fonika Kable SA GK & $\begin{array}{l}\text { Manufacture of computer, electronic and } \\
\text { optical products }\end{array}$ \\
\hline SYNTHOS SA GK & Manufacture of basic metals \\
\hline $\begin{array}{l}\text { BSH Sprzet Gospodarstwa Domowego Sp. z o.o.; Electrolux Poland; Indesit } \\
\text { Company Polska; LG Electronics Wrocław Sp. z o.o.; Philips Lighting Poland } \\
\text { SA GK; LG Electronics Mława Sp. z o.o. }\end{array}$ & Manufacture of electrical equipment \\
\hline Grupa CAN PACK SA; Michelin Polska SA & $\begin{array}{l}\text { Manufacture of fabricated metal products, } \\
\text { except machinery and equipment }\end{array}$ \\
\hline $\begin{array}{l}\text { Fiat Auto Poland SA; Fiat GM Powertrain Polska Sp. z o.o.; Grupa Magneti } \\
\text { Marelli; Grupa Valeo Polska; TRW Polska; Volkswagen Motor Sp. z o.o.; } \\
\text { VOLKSWAGEN Poznań Sp. z o.o. }\end{array}$ & $\begin{array}{l}\text { Manufacture of motor vehicles, trailers and } \\
\text { semi-trailers }\end{array}$ \\
\hline Grupa Saint-Gobain & $\begin{array}{l}\text { Manufacture of other non-metallic mineral } \\
\text { products }\end{array}$ \\
\hline Philip Morris Polska SA & Manufacture of tobacco products \\
\hline Swedwood Poland SA & $\begin{array}{l}\text { Manufacture of wood and of products of } \\
\text { wood and cork, except furniture }\end{array}$ \\
\hline $\begin{array}{l}\text { PGE Polska Grupa Energetyczna SA GK; TAURON Polska Energia SA GK; } \\
\text { ENERGA SA GK }\end{array}$ & Electricity \\
\hline
\end{tabular}


Table 15 Profiles of the examined subjects (Group TS - Poland)

\begin{tabular}{|c|c|}
\hline Name & Profile \\
\hline Totalizator Sportowy & Arts, entertainment and recreation \\
\hline $\begin{array}{l}\text { BUDIMEX SA GK; Grupa Skanska SA; Mostostal Warszawa SA GK; } \\
\text { POLIMEX-MOSTOSTAL SA GK; STRABAG Polska Sp. z o.o. }\end{array}$ & Construction \\
\hline $\begin{array}{l}\text { Alpiq Energy SE; ENEA SA GK; Energa-Obrót SA; ENERGA Operator SA; } \\
\text { EVEREN Sp z o.o.; PKP Energetyka SA; PSE-Operator SA; RWE Polska; } \\
\text { Vattenfall Energy Traiding Sp z o.o. }\end{array}$ & $\begin{array}{l}\text { Electricity, gas, steam and air conditioning } \\
\text { supply }\end{array}$ \\
\hline $\begin{array}{l}\text { ASSECO Poland SA GK; GETIN Holding SA GK; PKT Centertel Sp z o.o.; } \\
\text { Polkomtel SA; Polska Telefonia Cyfrowa Sp z o.o. }\end{array}$ & Information and communication \\
\hline Glaxosmithkline Pharmaceuticals SA GK & Pharmaceutical products \\
\hline Emperia Holding SA GK; PGB SA GK & $\begin{array}{l}\text { Professional, scientific and technical activi- } \\
\text { ties }\end{array}$ \\
\hline $\begin{array}{l}\text { Grupa PKP SA; Jeronimo Martins; PKP Cargo SA; PKP Polskie Linie Kole- } \\
\text { jowe SA; Polskie Linie Lotnicze LOT SA; PPUP Poczta Polska }\end{array}$ & Transportation and storage \\
\hline $\begin{array}{l}\text { AB SA GK ; abc Data SA GK; Animex Sp z o.o.; Auchan Polska Sp z o.o.; } \\
\text { BP Europa SE Polska SA; British American Tobacco Polska TRAIDING Sp z } \\
\text { o.o.; Carrefour Polska; Castorama Polska Sp z o.o.; Eurocash SA GK; Farma- } \\
\text { col SA GK; Grupa Metro W Polsce; Grupa Muszkieterów; Grupa Polomarket; } \\
\text { Grupa Shell Polska; Grupa Statoil Polska; Grupa Unilever; KGHM Metraco } \\
\text { SA; Kolpolter SA; LIDL Polska Sp z o.o.; Makro Cash And Carry Polska SA; } \\
\text { Media-Saturn Holding Polska Sp. z o.o.; NEUCA SA; Orlen Petrocentrum Sp. } \\
\text { z o.o.; Polska Grupa Farmaceutyczna SA GK; Polski Koks SA; PPHU Specjał } \\
\text { GK; PSH Lewiatan; REAL Sp z o.o.; ROSSMAN SDD Sp z o.o.; RUCH SA; } \\
\text { Samsung Electronics Polska Sp. z o.o.; SELGROS Sp. z o.o.; Węglokoks SA }\end{array}$ & $\begin{array}{l}\text { Wholesale and retail trade; repair of motor } \\
\text { vehicles and motorcycles }\end{array}$ \\
\hline
\end{tabular}


